\title{
Architecture and Perspective in the Set Drawings of the Galli Bibiena
}

\author{
Stefano Chiarenza ${ }^{1}$
}

Published online: 8 July 2016

(C) Kim Williams Books, Turin 2016

\begin{abstract}
At the end of the seventeenth century, a revolutionary process in themes and techniques involves painting. The perspective's rationality becomes the pretext for subverting the foundations and illusive dynamics of the architectural representation. In those years, quadratura painting and stage design become for the artists a common field of experimentation and spatial research. In this context, the artistic production of the Galli Bibiena both in scenographic and architectural field, it seems to have played a key role. This paper, after examining the relations between perspective painting and theatre scenes, and between built architecture and architectural imagery, focuses on a perspective analysis of the scene "drawing" of the Galli Bibiena. The aim has been to use perspective drawings as real project prefigurations, giving back through strict photogrammetry procedures, a great practicality and virtual materiality to the spaces and architectures simulated on the two-dimensions of the flat surface.
\end{abstract}

\section{Introduction}

Theatrical representation between the seventeenth and eighteenth centuries, as a privileged space for simulation, calls into play among other effects, a set of superb scenography, built on the visual reconstruction of space, capable of soliciting the evocative capacity of the viewer and, at the same time supplying brand-new spatial combinations. Such shapes, often generous or even bizarre, demonstrate the diffusion of these new models-real life formal prototypes whose transposition to stone would have come by osmosis with the new taste to which the drawn

Stefano Chiarenza

stefano.chiarenza@unisanraffaele.gov.it

1 Department of Human Sciences and Promotion of the Quality of Life, Faculty of Architecture and Industrial Design, San Raffaele Roma Open University, Rome, Italy 
architecture itself gave a significant burst. In such a context, the artistic production, both in scenographic and architectural contexts, of the Galli Bibiena, a true dynasty of set-designers and architects, appeared as a leading player, both for the new formal innovation introduced and for having fed the interest on perspective architectural compositions (Andersen 2007).

This paper, after examining the relations between perspective painting and theatre scenes, and between built architecture and architectural imagery from the end of the seventeenth century, focuses on a perspective analysis of the scene "drawing" of the Galli Bibiena. Research on the work related to the Bibiena that has been produced up till now has focused more on the artistic value and overall impression of the drawings, and less on perspective drawing as a tool that holds metric elements capable of giving a design value to the representations. In this paper, the aim has been to use perspective drawings, generally used to satisfy sight, as real project prefigurations, giving back through strict photogrammetry procedures, a great practicality and virtual materiality to the spaces and architectures simulated on the two-dimensions of the flat surface. Therefore the objective pursued does not try to highlight or show symbolic values-as often turned out in past researches, especially regarding Renaissance perspective-but to rebuild the architecture of the Bibiena, recovering, thanks to perspective, original drawings through which the architectural grammar of the artists can be read. This work, placed side by side with the other research done over time on the Bibiena, enriches them with additional meanings through a geometric-projective approach; in fact, if in some cases the Bibiena's architectural reconstructions were operated starting from autograph drawings in orthogonal projection, perspective drawings have been less frequently used for the same purpose, and not in a systematic way. Perspective's math has allowed the addition to the Bibiena's repertory the works that have been strictly kept in scenic imagery. The methods used highlight in particular the role and potential of the representation in terms of communication and documenting of the illusory spaces depicted in the Bibienas' theatre sets. Through solids modeling, put to work on two-dimensional drawings obtained by perspective and properly re-elaborated, it has been possible to give a volume consistency that, tangible as far as the digital environment, gives back to those virtual models the dignity of built architecture, with their own spatial interiors.

The research has examined a significant number of drawings edited by several artists of the Bibiena dynasty, but only for some of them has it been possible to identify the geometric conditions for applying the reverse perspective process. Leaving aside the many stage sketches, attention has been directed only to those for which it was possible to find a rather rigorous perspective setting. As an example of the procedure and the results, a specific case study is presented here. Through this case study it is in fact possible to fully highlight the set of reconstructive-logical thread analysis and scientific thought on the themes of the reverse perspective representation. Through the definition of a digital model, the drawn space was made usable, freeing its spatial component, in a new mise en scène, from the boundary and firmness of a unique point of view.

This paper, therefore, while not claiming to be exhaustive, aims to contribute to a broader reflection on the communicative and documentary virtues of the 
representation, especially if it is directed only to drawn architectures, such as those outlined in the capriccios and fantastic compositions that connote the stage production of the Bibienas.

\section{Perspective Painting and Theater Scene}

Even if the bonds between perspective representation and theater scene have been hypothesized since the first urban perspectives of the Renaissance (Kernodle 1944), both inlaid and painted (Chiarenza 2006: 77), the relations between painting and scenography are even more significant and certain with the illusory exercise of the quadraturistic wall decoration. Even stronger and profounder bonds seem to appear around the end of the seventeenth century, right when perspective illusion, after several schools, experimenting with many ideas and solutions, appears to fade away but without totally disappearing (see Figs. 1, 2).

The relationship between quadraturism and scenography is actually very clear, and not only because of the common theoretical inspiration, connected to real architecture and to Peruzzi, Palladio and Serlio's treatises (Negri Arnoldi 1983). Those forms of art, in fact, faced in parallel and with continuous communication and interferences, the same issues of spatial research (see Figs. 3, 4).

Experimentation with the "angled perspective", the "inscribed architectures" or the so-called "single diagonal perspective" built up compositive forms that came from a common territory of thought between painting and scenography to the point that, in some cases, the painting solutions forestalled the scenographic devices, as in the case of the Bibienas' quadraturistic decorations at the Fantuzzi palace in Bologna (Lenzi 2005: 275). As observed by Arnoldi, "the relationship between figure and architecture is untouched, either it is about fake architecture, or theatre

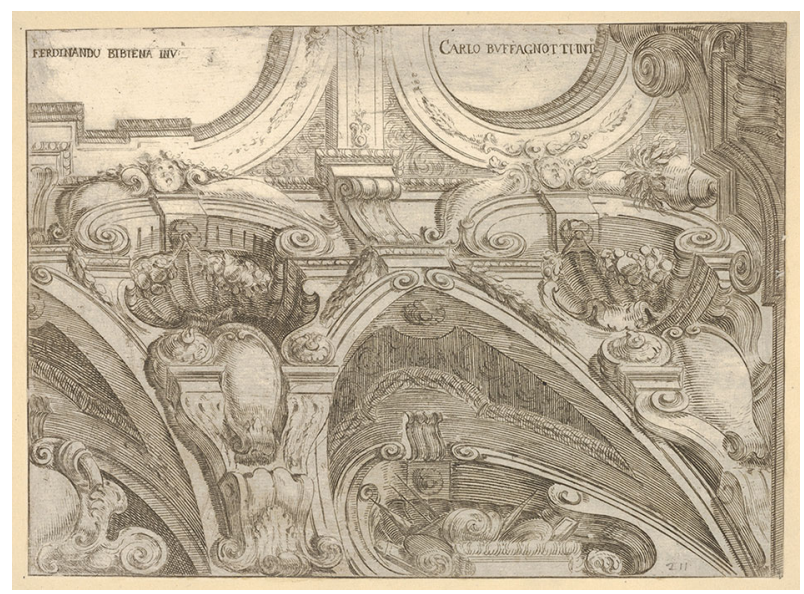

Fig. 1 Carlo Antonio Buffagnotti, 1660-1710, architectural detail. Image: The Metropolitan Museum of Art collection: http://www.metmuseum.org 


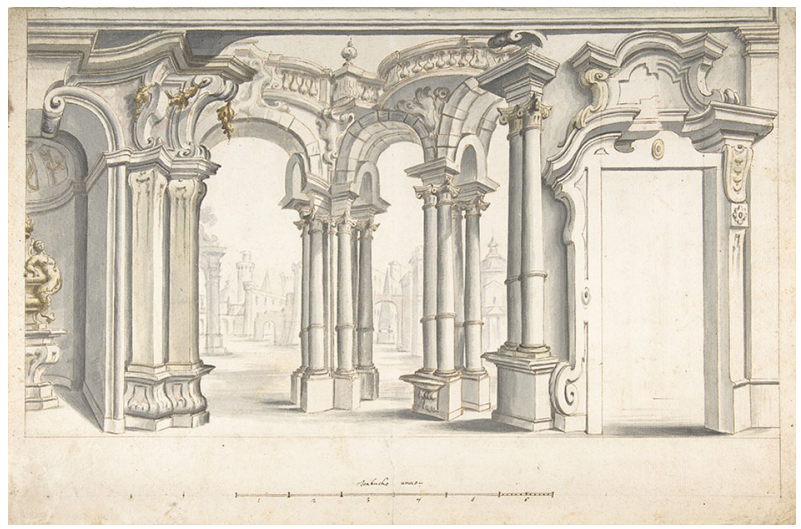

Fig. 2 Anonymous, Italian, eighteenth century, design for a painted perspective wall decoration. Image: The Metropolitan Museum of Art collection: http://www.metmuseum.org

Fig. 3 Drawing attributed to Ferdinando Galli Bibiena, 1657-1743, Foreshortened or Trompe L'Oeil View of the Architecture Surrounding a Courtyard. Image: The Metropolitan Museum of Art collection: http://www. metmuseum.org

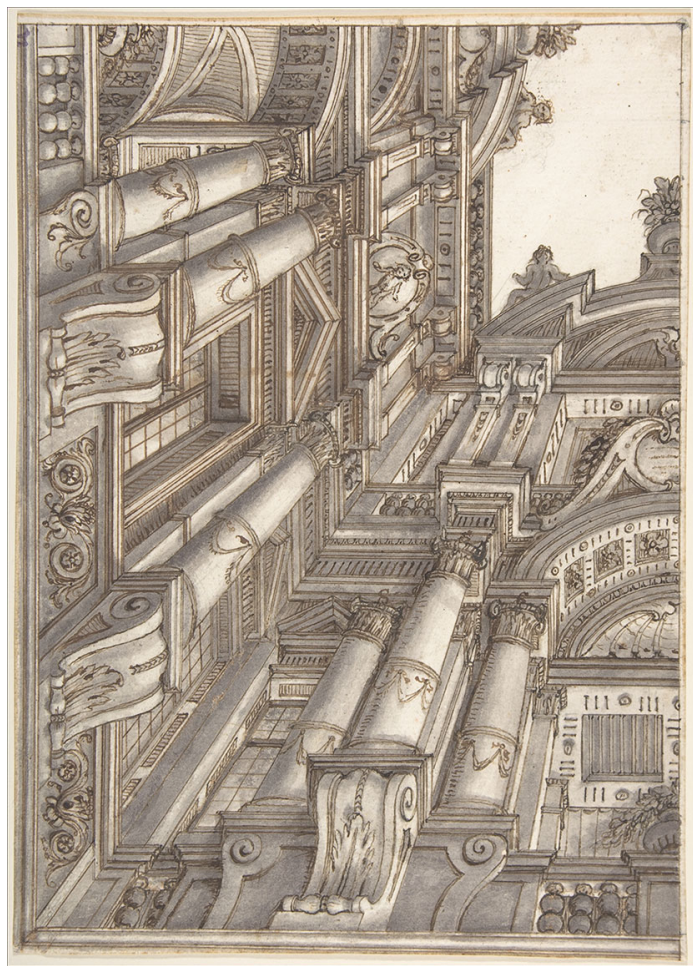

scenes, even if" in the latter case, we have to keep in mind "not only of the human presence but of its movement too. In this case it will be about a different placement of the fake architectures, but this placement will always follow the spatial development criteria, that even in the quadraturism, are meant to allocate the 
Fig. 4 Antonio Galli Bibiena, 1744-45, illusionistic painted dome, trinitarius Pozsony
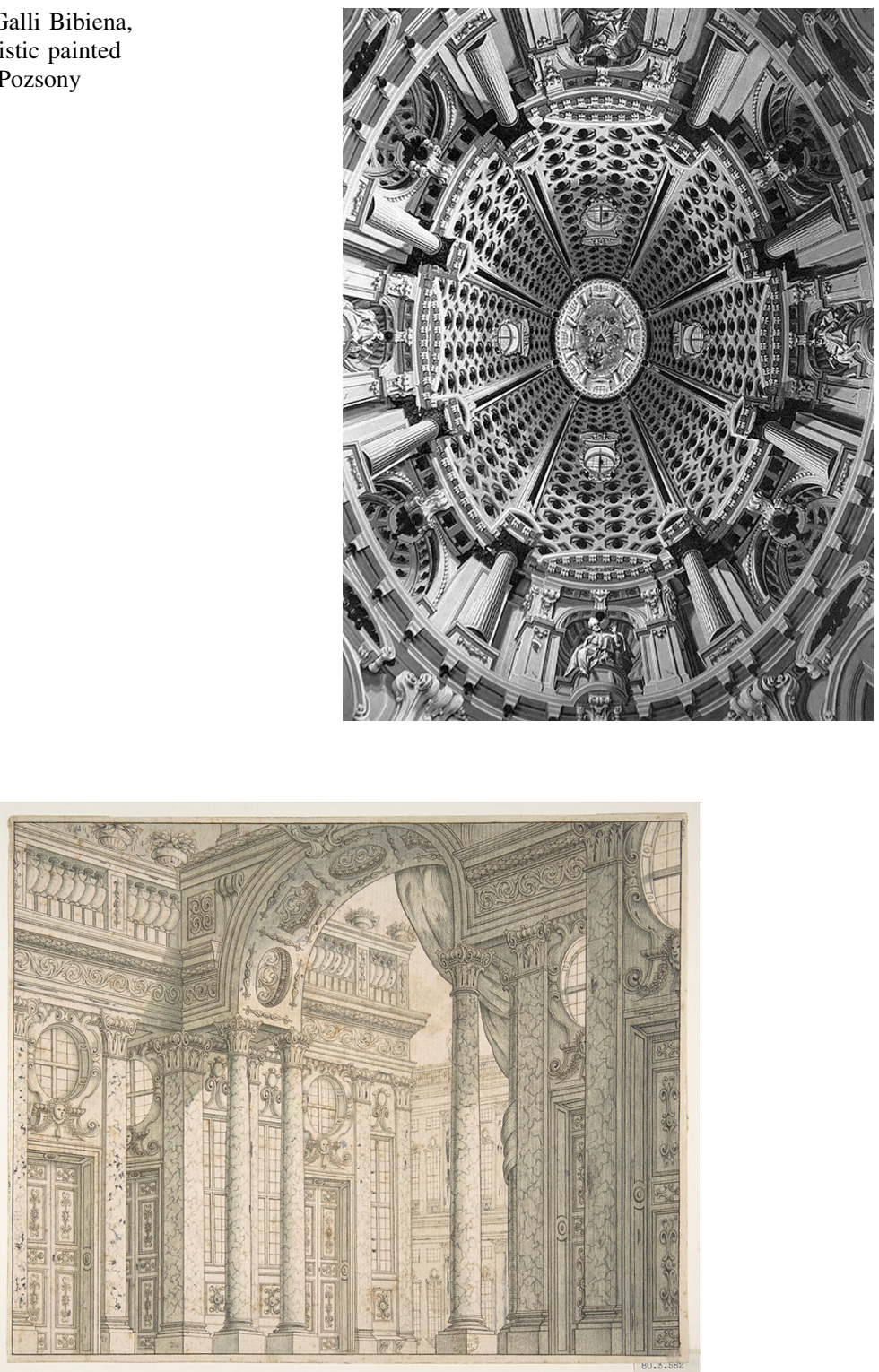

Fig. 5 Ferdinando Galli Bibiena, 1657-1743, Design of a Perspective for a Stage Set with Courtyard and Triumphal Arch. Image: The Metropolitan Museum of Art collection: http://www.metmuseum.org

environment to the representation of figures and episodes" (Negri Arnoldi 1983: 111) (Fig. 5).

It is not a straightforward process to distinguish between quadraturists and scenographers in the field of perspectivism, given that several painters have also committed to scenography and many scenographers, also the internationally known 
ones, have exercised in their career the art of perspective illusion painting. Amongst the several mentioned, some of the most important are the Galliari (Bossaglia 1958) (Fig. 6) and the Bibiena. The latter, specifically, grab and lead to perfection the artistic movement growing around architectural perspectivism with a series of refined devices, to the extent of being identified as the hinge of the new theatre scene of the eighteenth century. And it is especially in scenography that architectural perspectivism is totally freed from the breaks that image decoration required, surpassing the criteria of decoration towards spatial usage.

The fulcrum of perspective composition loses its centrality to visibly move towards the periphery of the horizon line, often anchoring itself to the elements of real architecture or of the theatre's set. In this way, the observer's eyes is pointed towards lines that lead to focus points outside representation and, in a theatre, placed to the scene frames side. The result is a new visual composition capable of supplying brand new expressive possibilities. As mentioned by Povoledo "it's a new and limitless dynamic in which each movement is reversible. And on each spatial line we see the continuous insertion of architectural elements that inscribe the vanishing points. And in this direction it proceeds, forking in two different directions, to the point that another and yet another "transparent" one repeat, infinitely extending the game" (Povoledo 1983: 272).

The application of the rules of perspective again give an order to the scene, but the concurring points multiply and the axes decentralize. The new perspective "machine" uses the stage space in different terms compared to the seventeenth

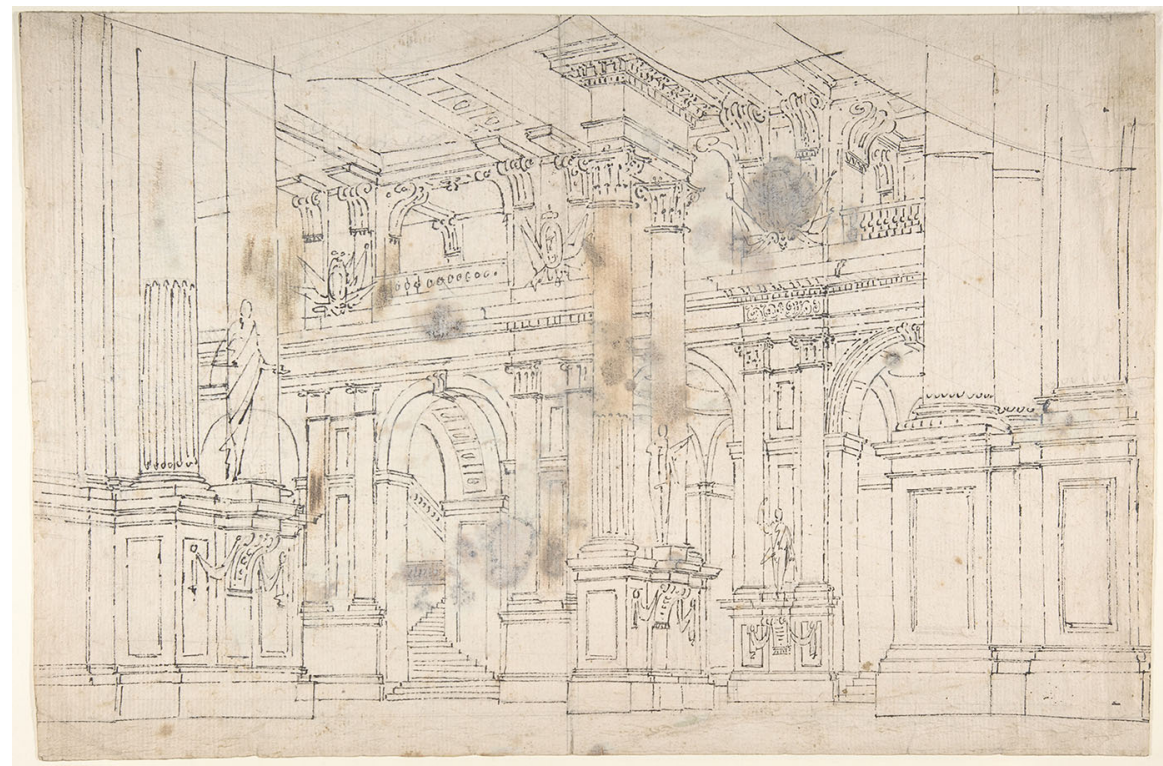

Fig. 6 Fabrizio Galliari, 1709-1790, Outline drawing: stage set design for a performance of "Iphigenia". Verso: Two designs for palace interiors. Image: The Metropolitan Museum of Art collection: http://www. metmuseum.org 
century. It divides the depth of the stage in two parts, designs the element of the proscenium and of the first segment on man, and uses the space left for the prospective image. The traditional background is interspersed with smaller perspective-perforated background components, placed along the central axis or asymmetrically (Battistelli 1986). Unprecedented vanishing points, in diagonal, unhinge the spatial unit of the scenic environment with highly involving results for the spectator (Fig. 7).

\section{Architecture and Architectural Imagination}

From the point of view of architectural theories, eighteenth century Italy appears in a subordinated position compared to France and England. For what concerns optical geometry and the application of perspective, Italy plays a fundamental role in all Europe. While geometry and stereometry characterized Guarini's work, with significant outcomes in the architectural theories of the Baroque, the problems regarding perspective representation had catalyzed, since the late seventeenth century, the interest towards architectural representation and optical effects.

As written by Kruft: “... architecture comes close to theatre scenography with a 'scene' effect. Correspondingly, the real architecture often has the appearance of a theatrical wing. We can recall for instance piazza S. Ignazio in Rome (1725-36) by Filippo Raguzzini” (Kruft 1988: 255). The profound interaction between reality and representation is clear to see, which is an intellectual message itself in the-almost design-articulations that highlight imaginary architectures of which the elegance, often extremely pushed, is graced by the graphic efficacy of perspective. This kind of work particularly is highlighted in the Galli Bibiena's art, the famous family of scenographers and architects, whose artistic momentum spread fortunately not only

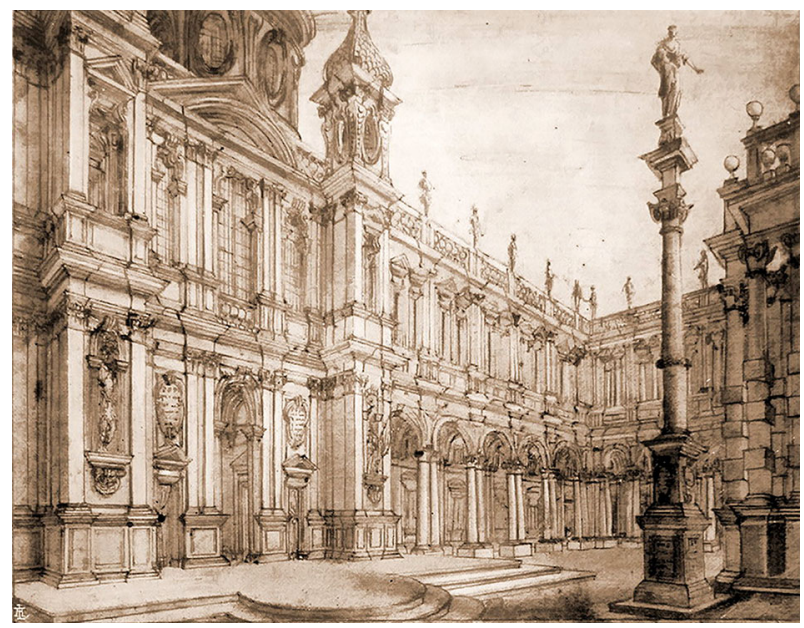

Fig. 7 Ferdinando Galli Bibiena, 1657-1743, Cortile e Chiesa di una reggia. Image: The Metropolitan Museum of Art collection: http://www.metmuseum.org 
in Italy but also in many and wide Mediterranean and Germanic European regions, up to Lorraine (Gallingani 2002).

The founder of the artists' family was Giovanni Maria Galli (the elder) (1618/ 19-1665), painter, born in Bibbiena, a small town in Toscana. His children were the painter Maria Oriana (1656-1749) and the better known architects and scenographers Ferdinando (1657-1743) and Francesco (1659-1739) who actually gave birth to the dynasty.

While Maria Oriana, the father's pupil, expressed herself as a mannerist painter, with no original contribution, the brothers Ferdinando and Francesco trained as architects, scenographers and painters, were the authors of the new points of view introduced in built architecture, in perspective drawing and in scenography, and, with regard to the latter, in particular, they theorized the revolutionary "angle view" as a substitute for the seventeenth century "telescope view" (Lenzi 1991; Mancini 1979, pp. 302-370; Matteucci 1982, pp. 129-131). Their fruitful activity, often collaborating in several parts of Europe, fed a renewed interest for architecture's perspective view, especially in France, Austria and Spain.

Of Ferdinando's offspring, his sons Alessandro (1686-1748), Giovanni Maria the young (1693-1777), Giuseppe (1696-1756) and Antonio Luigi (1697-1774) followed the father's path, starting their careers in architecture, painting and theatre scenography and transmitting the family tradition to the following generation. Francesco's son was Giovanni Carlo Sicinio (1717-1760), who was an architect himself.

The latest notable exponents of the family were Giuseppe's sons, Carlo Bernardo Giuseppe (1721-1787), born in Wien, known for his collaborations with his father and for his formation as an architect, painter and scenographer, and Ferdinando Antonio (1727-unknown).

So with Ferdinando and Francesco we see a new orientation of perspective decoration, with a sensitization towards the taste for marvelous shows. If the visual source seems to be the one of Andrea Pozzo and Canaletto's tradition, in the plan of architectural creation we can see a brand new thinking on the theme of space. Fredinando's work Architettura civile, preparata su geometria e ridotta alla prospettiva from 1711, does not highlight the introduction of original and notable principles of architecture, but it introduces perspective diagrams that will leave a sign over the European scenography tradition, especially for changing significantly the relationship between representation and reality.

It is about the way of drawing scenes from an angle (modo per disegnare le scene vedute per angolo), a scenographic technique that breaks the central perspective point of view offering unusual lateral glances. The composition of the architectural scene was made in order to show the buildings angled from the spectators' view to achieve diagonal points of observation.

The first experimentation with such structures can be seen in painting, when, in Parma, on Scipione Rossi's duty, Ferdinando created, between 1685 and 1687, the fresco of the Serraglio oratory at San Secondo Parmense, of which he'd probably also done the architectural project. Here he paints perspective frescos on the walls and apses of the building, in the most ancient 'angular' point of view known (Galli Bibiena 1711, 1731), which is the creation of a perspective system that substituted 
diagonal perspective vanishing points for the known seventeenth century composition schemes, which broke the closed space. He paints this experimentation in scenography again, with totally innovative results.

With this scheme "he succeeded in conveying with the required grandeur and pomp the fantasy, mobility and the dynamism of fragmentary and intermediate spaces in the actual space of the stage and in its virtual extensions. Sinuous arcades held up by consoles, arrangements of grouped caryatids, wreathed columns decked with garlands or sculpted bosses of geometric ornaments alongside medallions, curvilinear pedestals and a profusion of balustrades. This elaborated decorative approach fixed the illusionary space of a vestibule, a huge stairwell or gallery leading out into a garden" (Rabreau 2001: 58).

While it recalls the sixteenth century practice of creating the multiple vanishing point theatre scene, usage of this kind of view can be considered a true innovation

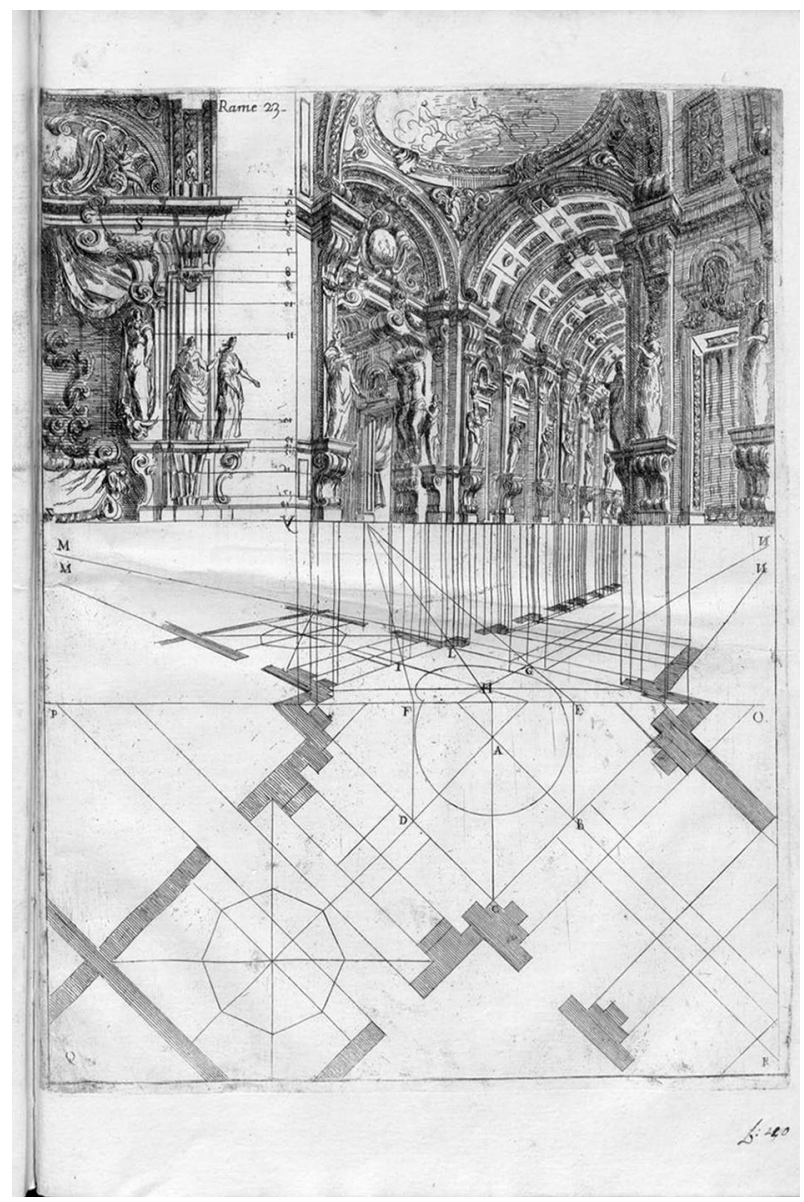

Fig. 8 Ferdinando Galli Bibiena, 1657-1743, Interior perspective of a church—rame 23—L'Architettura Civile, 1711 
by Ferdinando Bibiena; scenic architectures, in fact, appear to cross the stage diagonally and, in hiding from the viewer part of the space represented, it excites the evocative capability. In this regard, Martin Kemp notes that the advantage of the technique had a double turnout: it was suitable for the creation of dramatic effect and architectures with different degrees of depth; and it was less vulnerable to the distortion effect given by the spectators' positions. Of course the use of volumes diagonally arranged was not, in itself, a new idea-an example in this sense is the Brunelleschi tablet with the Signoria palace, based on a similar scheme-and already set designers had previously used diagonal elements; but Ferdinando Galli Bibiena was the first to employ the "angle view" in a dominating and totally compelling way (Kemp 1994: 160).

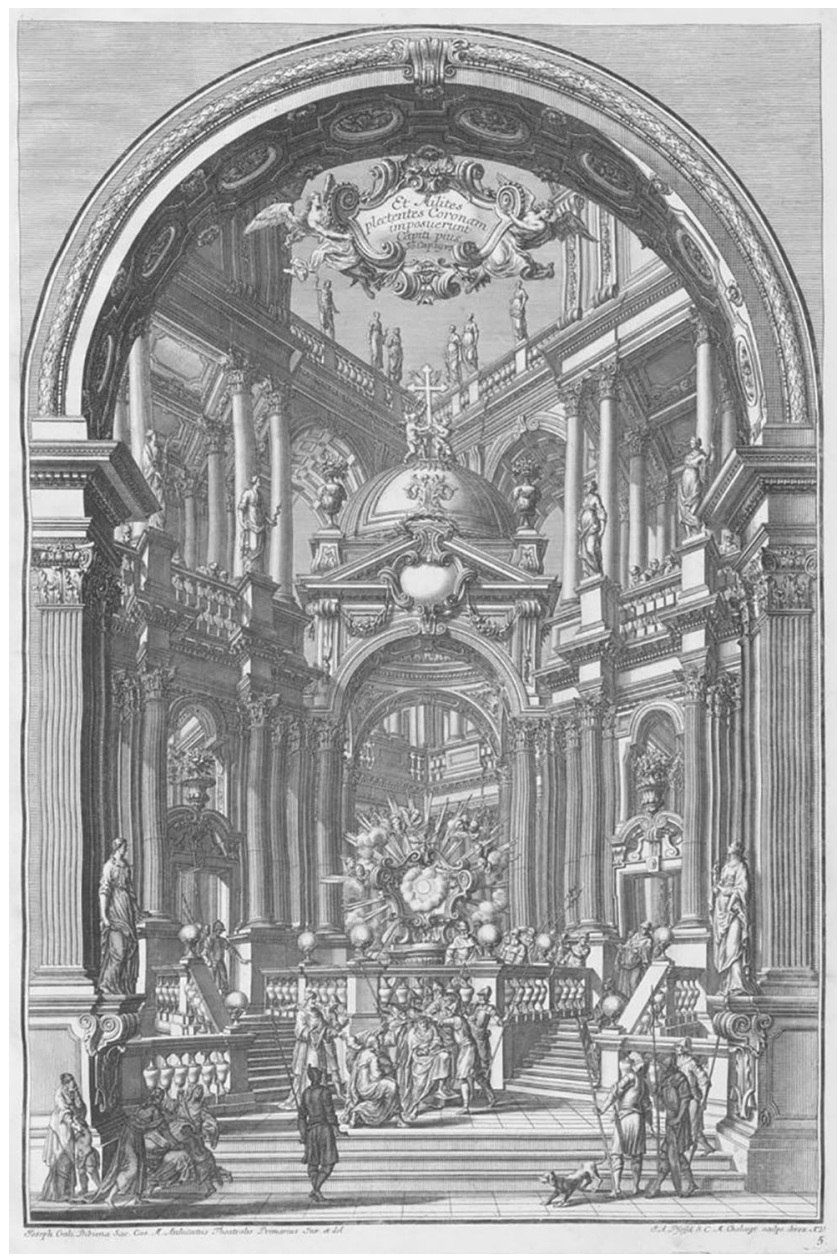

Fig. 9 Giuseppe Galli Bibiena, 1696-1757, Architectural perspective, tav. 5-Architetture e Prospettive, 1740 
In contrast with what used to happen in Baroque scenography, in which the space was literally simulated, inviting the viewer to a direct and aware participation in the illusion, but in which real space and representation were in contrast (Ruffini 1972), Bibiena, fascinatingly, determines a sort of homogeneity between the physical space and its representation. From the architectural point of view, the scenographic image highlights suggestive spaces, with surprising decorative effects, leaving interpretational freedom - that can never be mistaken-in the constructive structures. The impressive truth, together with scientific precision, pervades Bibiena's new inventions, striking "... a strong tendency to normalize the show of the eighteenth century towards an 'illusion' fed with 'verisimilitude' (Perrelli 2004: 123) (see Figs. 8, 9).

As written by Rabreau “... all of the Bibiena family enchanted Europe and their designs, which were sometimes engraved, bear witness to a civilisation that was in love with the theatre" (Rabreau 2001: 58). Amongst Ferdinando's sons Giuseppe was the one to give an essential contribution to the graphic work of the time, operating in several European courts. An excellent painter, with a solid theoretical preparation, he is fascinating because of his incredible versatility (Galli Bibiena 1740). He produces drawings that, even though oriented to scenography, often surpass its boundary, proposing a repertoire of images that impresses for its originality. In fact Giuseppe was able to create original compositions, notwithstanding Ferdinando's repertory, with its luxurious decorations and the charming angular scenography, which started the fashion and somehow concluded the

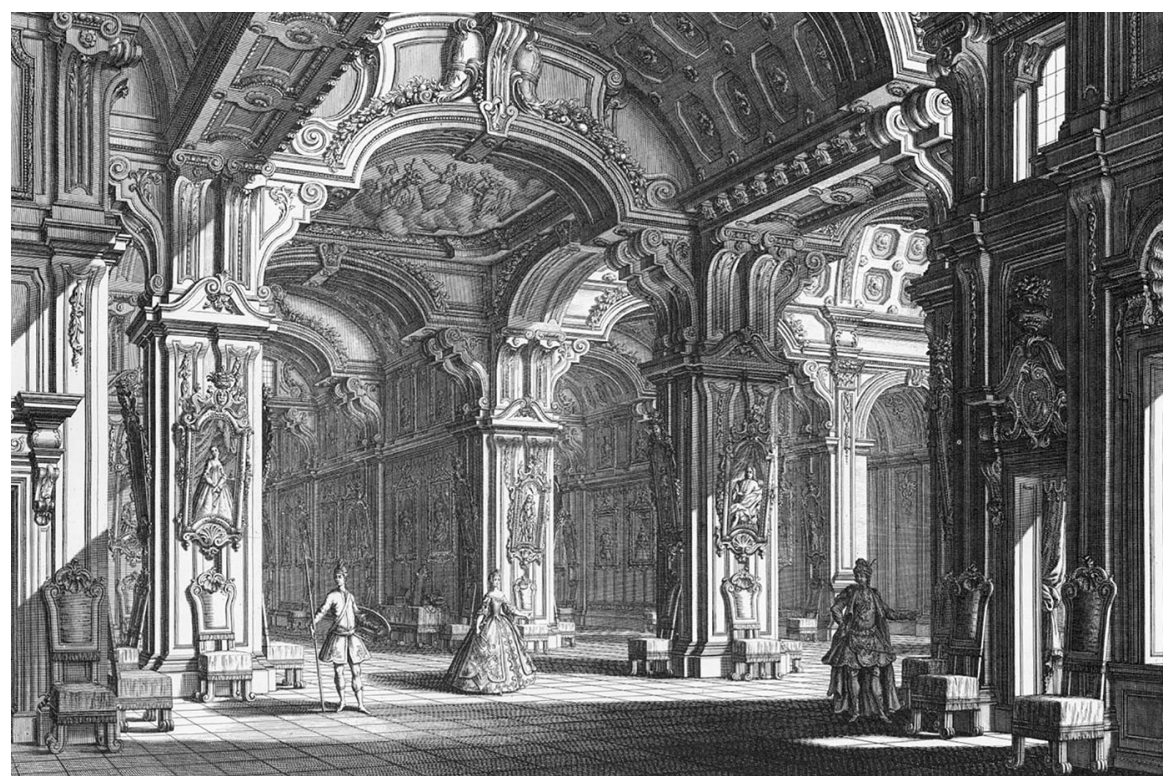

Fig. 10 Giuseppe Galli Bibiena, 1696-1757, Scena della Festa Teatrale in occasione delli sponsali del Principe Reale di Polonia ed Elettorale di Sassonia, tav. 40-Architetture e Prospettive, 1740 
innovative effect of the scenographic or architectural illusionist perspective drawing effects.

Great luminous architecture that allows glances of several perspectives, at first sight appears similar to his father's, but, analyzed in depth, highlights the research of a bare magnificence, relieved by the majesty of ornamental details. In this way, greater prominence is given to the sharpness of the architectural orders and their measures. In compositions, Giuseppe challenges his imagination, designing architectures characterized by thin and significant supports made up by sequences of tight pillars or perforated groups of columns that rest on pedestals, crowned with trabeations on which extremely scenographic arches were placed. Vault and lacunar ceilings, of any type, were the closure of what can be defined as extraordinary areas of fantasy (Fig. 10).

The Bibienas' prefigurative strength has an undoubted influence over built architecture. The scenographic spatiality drawn on paper quickly influences the creative vision of several architects of the time, anticipating the architectural shapes that characterized the transition between the Baroque and the Neoclassical tradition. It is not hard to find how, in the works of Dotti, Juvarra or Vanvitelli-just to mention a few-the spatial implant recalls Bibienas' drawings: it is enough to recall the scenographic project of the Meloncello arch in Bologna, or the one of Stupinigi hunting lodge or again the visual strategies of the Reggia di Caserta vestibule (De Seta 2002) (Fig. 11). But actually it is not the transposition of unique ideas that sees the design inventiveness from the drawing pass into architecture. The Bibienas' rich and sometimes repeated architectural grammar, cleverly juggled with graphic

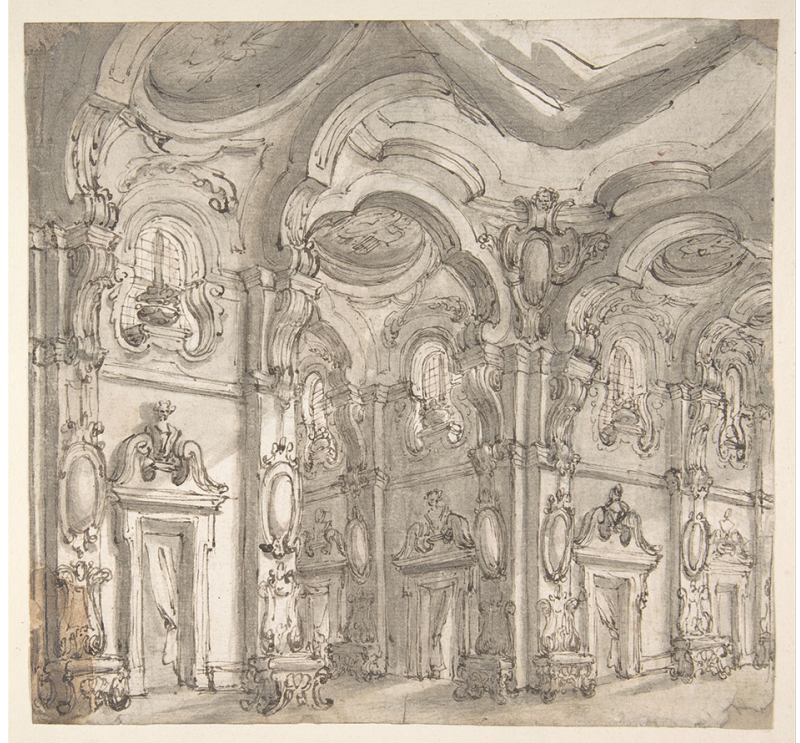

Fig. 11 Giuseppe Galli Bibiena, 1696-1757, design for a stage set: the gallery of a magnificent palace decorated with mirrors. Image: The Metropolitan Museum of Art collection: http://www.metmuseum.org 
devices that take spatial and decorative compositions to the limits of verisimilitude, often appears to reference built architecture itself, echoing a Baroque expressivity in a renewed inventive. So we have a significant correlation between real and unreal architecture, a mutual influence connected to the ideas and visions of interpenetration, so that the drawing and its architectural audacity feed the creative pulse while real construction becomes nourishment for the anticipating imagination.

\section{From Image to Space}

The relationship between imagined and real architecture is brilliantly witnessed in all the drawings of the Bibiena, which therefore build up significant sources for the historical investigation of cities and architecture. On such figurative documents, a study approach based uniquely on the traditional iconographic model, which is a descriptive reading of the architectural shape and its parts to rebuild the relationship between the artwork and the historical-cultural context that has produced it, would be partial and unsatisfactory. In fact, since in the Bibiena drawings the perspective representation of architecture is made by architects, this method would not be totally exhaustive.

So, it was felt useful to investigate this particular type of image by heading for a reading that could be intimately related to the knowledge of cultural codes that are the basis of the work.

This paper illustrates the method through which the strengthening of the figurative interpretation of these works was achieved, and to the comprehension of the relationship between built architecture and its possible real structure that is a specific research field of the geometric representation of the architecture, to which this paper is aimed.

The Bibienas' drawings, whose atelier production means that the original products are not always able to be identified, have a very rich series of architectural scenarios, some realized as sketches for theatre, others with a didactic inclination within treatises, or as actual projects for decorative apparatuses, architectures or architectural elements. Most are drawn using perspective. This method gives the opportunity to propose for such drawings a different and more significant reading. In other words, it is possible to highlight in a more complete way the set of architectural shapes and urban spaces that have often been thought through, of which it would be hard to have a clear idea with any other interpretative analysis. Investigating with operations of reverse perspective, possible thanks to a strict methodical setting, we can see in their wholeness the spatial and metrical qualities of those acrobatic buildings, enclosed in the fixity of an image.

This research is even more significant if we consider that the architectures we have in the representations are pure fantasy, but at the same time the result of the architect-artist's inventiveness. ${ }^{1}$ So it is interesting to supply an articulate view of

\footnotetext{
${ }^{1}$ It is recognized that this approach does not constitute, in itself, a novelty in methodological terms, having been repeatedly used to reconstruct the illusory space outlined in many and representative works of art history. However, this method has been applied almost exclusively to pictorial art production; less frequently to scenic composition, especially that of the Bibienas.
} 
those drawings, identifying, in the variety of the images seen, the examples that can exemplify the characters of architecture that had clear reflection on the planning activity.

Amongst the several scenes in the Bibienas' repertory, just some of the most significant have been chosen for the first phase of this research. These are the ones that have three clear main figurative themes that in a certain way are the leitmotiv of scenic invention: first, the exteriors or porticos; second, winding stairs; and third the perspective view of interiors. In this paper, as an example of the method used, the work on a Design for a Stage Set with a Monumental Arcaded Courtyard is shown. It is attributed to Giuseppe Galli Bibiena and preserved in the Metropolitan Museum in New York.

Before passing to a rigorous analysis of the perspective structure, it is interesting to start with a pre-iconographic description. This means to define the elements of the image's structure and to give a reading of the composition.

The drawing shows a wide covered path, probably just a passage, arranged in an angled perspective that allows a glance, through wide arches, to an open air patio, placed on a slightly taller elevation, beyond which there are, repeatedly according to a strict modular scheme, the architectural elements of the type in which the represented architecture is articulated.

The passage, characterized by a precise structural logic, is repeated according to a rhythmical sequence of double columns, of composite order, that build up the support for the monumental arches. The architectural space is closed on top by a coffered ceiling divided in wide frameworks whose order is regulated by the columns' distance. The decorative interpretation is very variegated but at the same time moderate. So the large octagonal coffers are embellished with geometrical figures, the same as for the intrados of the arches; the mural hatches are adorned with raised pattern medallions and the arches' keys enriched with projecting shields surmounted by moving patterns. The moldings, from the classical orders, are varied in the pedestals by unusual curved profiles. The first floor route crosses a bigger space that runs orthogonally, and exceptional solutions at the intersection of these spaces are adopted, to give the scene the character of elegant magnificence, such as the doubling of the thickness of the arches, or the insertion, in the angles, of niches with statues and busts.

When trying to apply a reverse perspective procedure to the image studied it is important to analyse the composition with greater attention compared to its geometrical structure. It is easy, first of all, to see that the perspective structure of the image is vertical. All the vertical edges drawn, in fact, are parallel mutually and with the picture plane. The setting of the drawing, furthermore, follows the basic setting of the angle scene, presenting an $\mathrm{X}$-shaped architectural plan, for which the right angle is $45^{\circ}$ compared to the picture plane. In this way, the vanishing points of each of the principal straight lines, mutually orthogonal, will be placed on the $90^{\circ}$ circle of view at the intersection with the horizon. This circumstance eases the determination of the internal orientation of the reference in the picture plan (view center, horizon and observer distance) and easily allows us to trace it; in fact, extending the straight lines of the two bundles-which in reality would be mutually orthogonal-we find two $45^{\circ}$ vanishing points, that will be crossed by the horizon, 


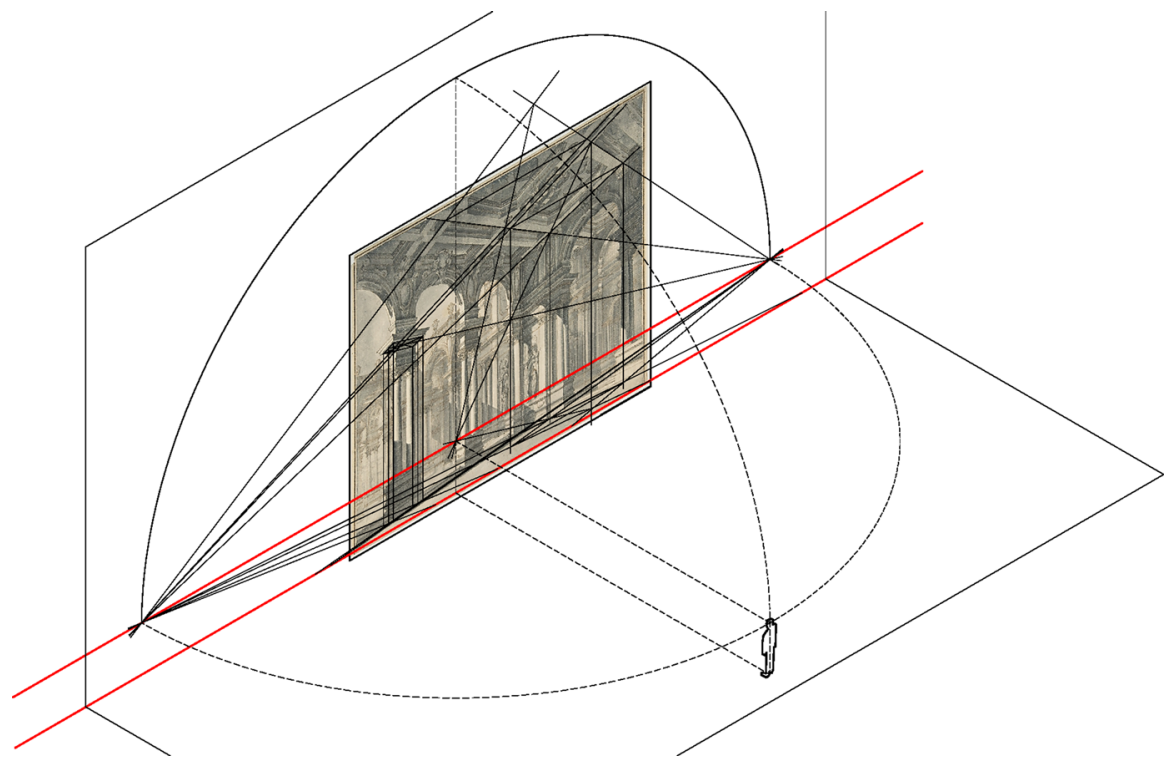

Fig. 12 Three-dimensional scheme of the elements of perspective reference. The position of the observer appears as in a theatre auditorium area

and will turn out to be orthogonal to the vertical lines. The same two vanishing points are the external points of the diameter of the $90^{\circ}$ circle of view, with center in their middle point (view center). The ground line has been considered to be the horizontal line at the base of the drawing, as it was the praxis used for the reverse perspective procedure applied to scenic sketches ${ }^{2}$ (Fig. 12).

So we proceeded to a reverse perspective representation, paying particular attention to the proportional articulation of the architectural order. Apart from the pedestal, which represents an exceptional element that cannot be referred to the traditional rule, only minimum changes have appeared, which can be considered negligible compared to the correct proportion. To determine the latter, we've derived height and base of the column and, following the rule in the theoretical essay by Ferdinando Galli Bibiena (L'architettura civile), we moved on to the proportioning of the different parts of the order. Unimportant inaccuracies due to the painting instrument have been left out, or approximated following the correct proportions. More freedom has been exercised in the representation of the decorations, for which the ink traces of the drawing have sketches of ideas which are voluntarily undefined and adapted, with less precision, to the strictly calculated basic perspective pattern. All of the elements have been redesigned on the basis of a critical investigation based on similar documentary sources (other drawings that can be attributed to the same school), and a critical reading of the treatises of the Bibiena themselves (Fig. 13a, b).

\footnotetext{
${ }^{2}$ A different position of the ground line would not lead, anyway, to any metrical, geometrical and proportional change.
} 


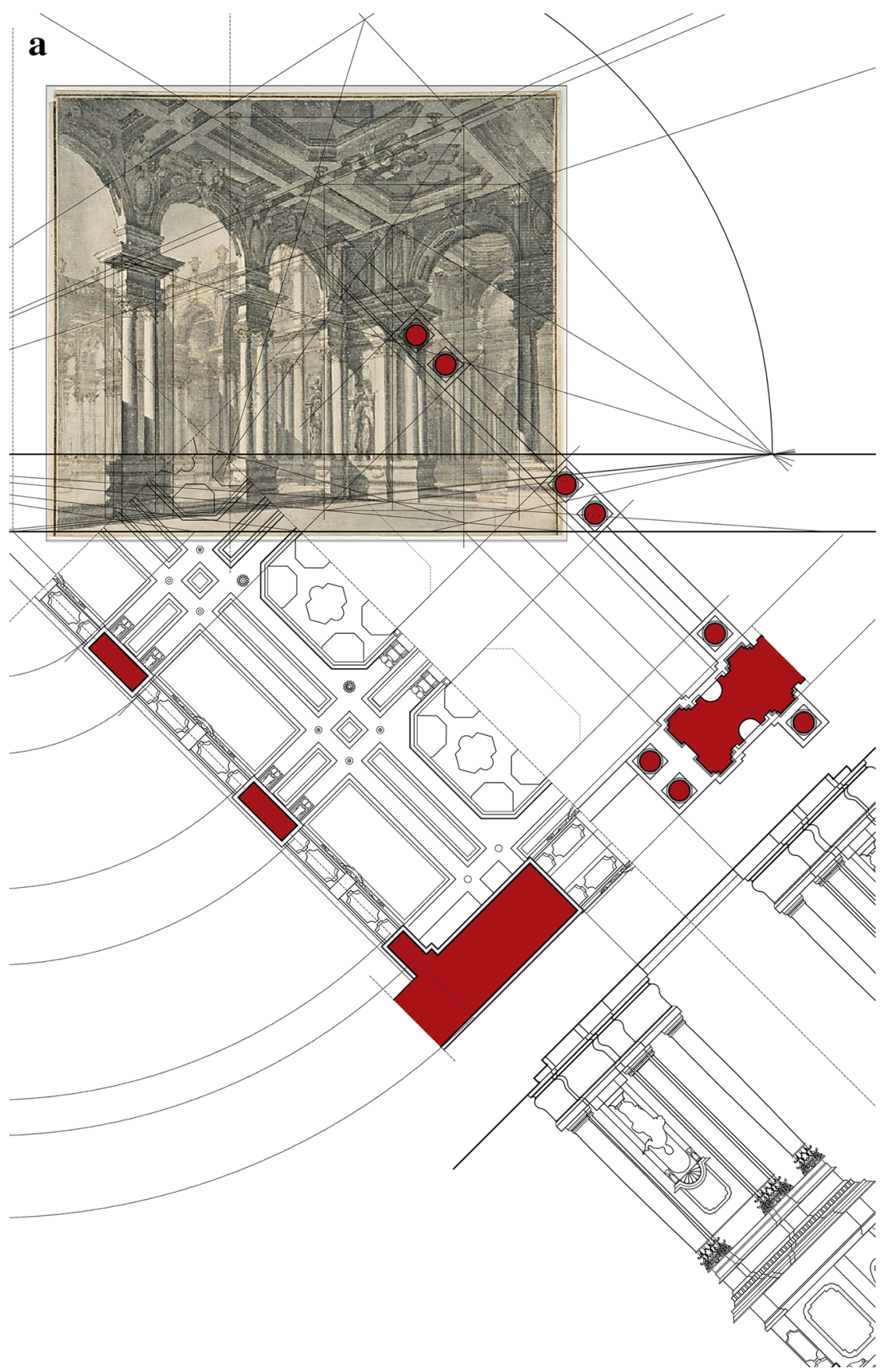

Fig. 13 Reverse perspective: the plan and one of the internal elevations from the Giuseppe Galli Bibiena drawing 'Design for a Stage Set with a Monumental Arcaded Courtyard' (elaborated by Stefano Chiarenza) 


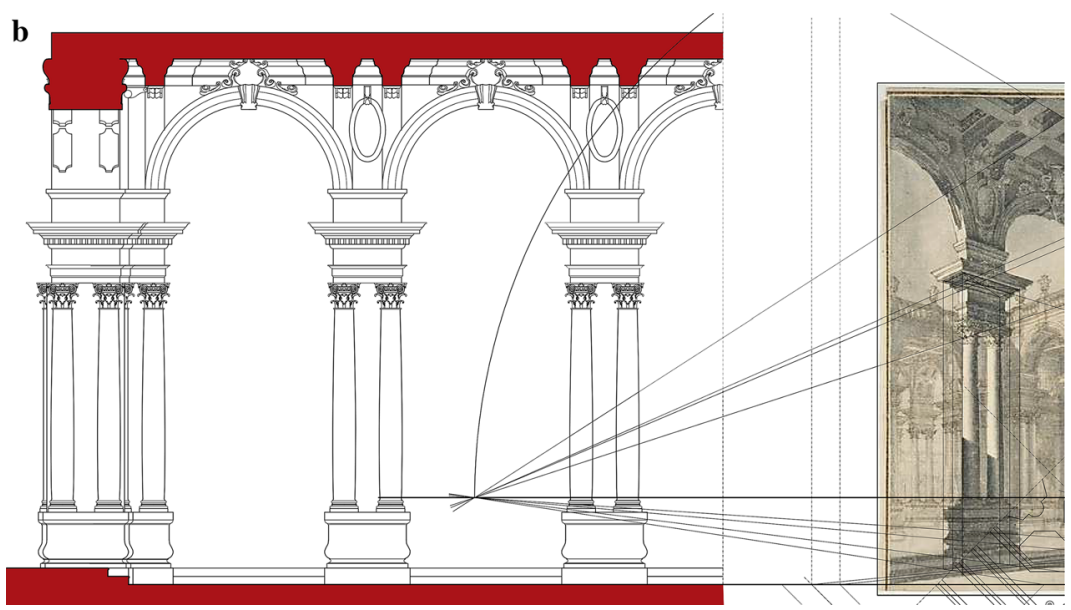

Fig. 13 continued

To offer an image that could have concreteness, it seemed appropriate to reproportion some elements, especially the ornamental ones in order to regulate the clear inaccuracies. This redefinition allowed us to represent with geometrical strictness each and every part of the imaginary apparatus, and to achieve a defined space through architectural drawings in orthogonal projection, starting from which a solid infographic model could be built. This kind of 3D modeling, obviously, catches the visible part of the space, extending it only to the portions that can be hypothesized in relation to the modular nature of the structure. Through the solid model it was possible to move the point of view through an architecture that was somehow real, or at least explorable in its spatial architectural values. The efficacy of this kind of representation is in the materialization, with no limits, of an illusory space and in the possibility of representing information that could enhance our comprehension and prefiguring capacity of the Bibienas. The mathematical fundament of representation allows, so, the passage from a scene perspective, born to trick the human eyes, to the reconstruction of an architectural-type project (Fig. 14).

\section{Conclusions}

As observed, the experiences in architectural painting between the seventeenth and eighteenth century highlight a significant connection between architecture and perspective, intended as a means to enlarge and deceptively iterate the real space. In its integration with real space, perspective-drawn architecture on walls or vaults loses trompe-l'oeil significance, rather gaining the status of simulated real spaces which enlarge or modify the qualities of the existing ones. This type of painting, for this reason defined as quadraturist, demonstrates a common denominator and a common research field with theatre scenography, that sees the birth of huge 


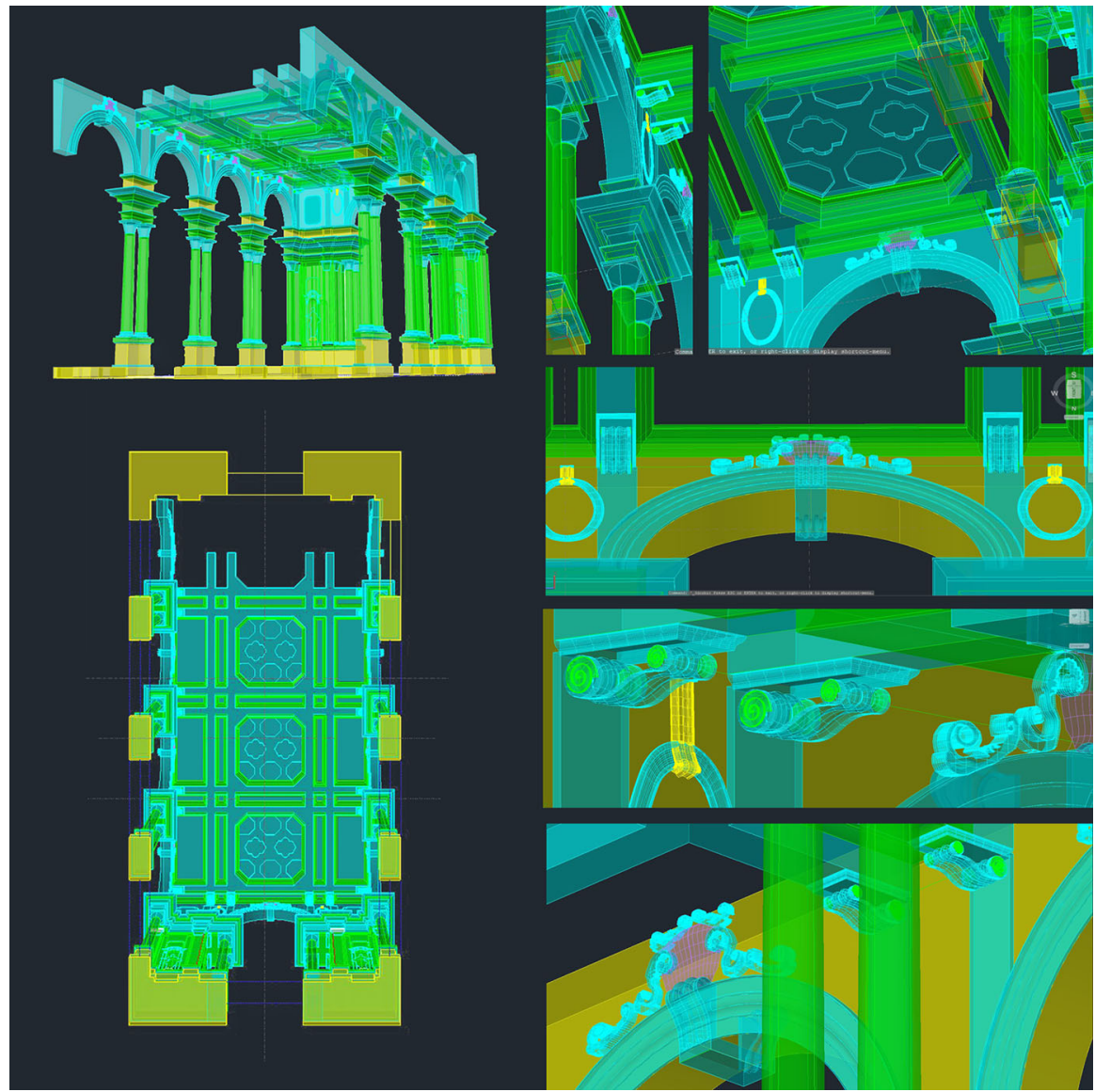

Fig. 14 Details from the infographic model of the 'Design for a Stage Set with a Monumental Arcaded Courtyard' (elaborated by Stefano Chiarenza)

perspective architectural scenarios. In the theatre scenes it was the Bibienas, in Europe, who were the most important interpreters of architectural perspectivism and also important innovators of the perspective view who gave, with the angular setting, a new rigor that brought attention back to the values of drawn architecture. The Bibienas are both architects and scenographers. The scenes drawn by the artists of this family are, for this reason, precious documents not only in the field of scenic arts, but also in architecture. The contribution of their drawings, however, is often ascribed to the field of figurative arts, more than in architecture, and in this sense the architectural research on their family is nowadays led by historians.

This research, instead, wants to highlight how the perspective construction of the drawings, which is their realization according to a mathematical projection device, can offer the possibility of rigorously extracting, from perspectives, the traditional orthogonal projections, giving a stronger valence to sights that have been considered, till now, a purely artistic exercise. In the theatrical perspectives of 
the Bibienas, therefore, as in similar pictorial examples, "... the existence of a correct perspective construction assures us a documentary contribution..." fundamental to the interpretation of the represented architectural reality, of which "... we understand shapes and size... we can read links and suggestions often lost... and critically deduce useful elements to rebuild, metrically, the architectures that make up the fragment of the represented city" (Giordano 2014: 615).

The application of the photogrammetry procedure (or reverse perspective) to historical drawings, however, can't be a mere mechanical application obtained by software. It has to be thought through and corrected where necessary, using an interpretation technique based on the study of the proportioning rules of orders and architectural space. Orders and proportions can be found in the theoretical work of Ferdinando Galli Bibiena, and it was the starting reference for the reconstruction and the graphic verification of the scenic architectures analyzed here. In this regard, the research has allowed us to verify that-only excluding some decorative details or marginal architectural elements with respect to the entire composition-the proportioning rules of the orders, contained in Ferdinando's treaty, are mathematically applied in the drawings of the scenic images. Shapes and proportions of perspective architectures, conceived as theatrical wings, are fully corresponding to those theorized in the theoretical work of the Bibiena.

The potential of digital drawing and solid modeling allowed us to rebuild the architectures as virtual projects, that can be explored from different points of view, as shown in the illustrations. As already clarified, although the research has analyzed a great number of drawings, in this paper just one case has been presented as a sample of the methods applied. Indeed, we believe that, independently from the number of described examples, it is especially important to highlight the value of the graphic-geometrical approach, used as an investigation tool that can be added to the traditional ones, especially in relation to the Bibienas' works, whose scenes can be read as documents of actual architecture. In other words, the stage drawings of the Galli Bibiena-by combining the geometric-projective interpretation offered by the reverse perspective (which is preliminary to the metric definition of the space) with the interpretation and verification of the proportioning rules theorized in the treaty of Ferdinando Galli Bibiena (useful for the complete definition of each composition's element)—become a valuable documentary basis for reconstructing the architecture that is represented in them.

It has been demonstrated, through the connection with perspective, how drawn architecture can be re-read as a precious document that helps us understand the architectural grammar of the Bibiena.

\section{References}

Andersen, Kirsti. 2007. The Geometry of An Art. New York: Springer.

Battistelli, Franco. 1986. Piante delle scene di Ferdinando Bibiena per l'antico teatro della Fortuna e "annotazioni per chi opera" in un manoscritto inedito del secolo XVIII. In: Nuovi Studi Fanesi, I, pp. 131-151. Fano: Biblioteca Comunale Federiciana. 
Bossaglia, Rossana. 1958. Affreschi dei Gallinari nelle Ville Lombarde. Arte Lombarda 2, anno III: 105-113.

Chiarenza, Stefano. 2006. Architettura e Spazio nelle Città Intarsiate. Napoli: Giannini Editore.

De Seta, Cesare. 2002. Vanvitelli Scenografo e la Tradizione dei Bibiena. In: I Bibiena: una Famiglia in Scena: da Bologna all'Europa, ed. Daniela Gallingani. Firenze: Alinea.

Galli Bibiena, Ferdinando. 1711. L'Architettura Civile Preparata su la Geometria e Ridotta alla Prospettiva. Parma: per Paolo Monti.

Galli Bibiena, Ferdinando. 1731. Direzioni della Prospettiva Teorica Corrispondenti a Quelle dell'Architettura. Bologna.

Galli Bibiena, Giuseppe. 1740. Architetture, e Prospettive, Dedicate alla Maestá di Carlo Sesto. Paris: Bascan.

Gallingani, Daniela (ed.). 2002. I Bibiena una Famiglia in Scena: da Bologna all'Europa. Firenze: Alinea

Giordano, Andrea. 2014. La Città Dipinta di Canaletto tra Espansione dello Spazio e Visioni Dinamiche. In: Città Mediterranee in Trasformazione. Identità e Immagine del Paesaggio Urbano tra Sette e Novecento, eds. Alfredo Buccaro and Cesare De Seta. Napoli: Edizioni Scientifiche Italiane.

Kemp, Martin. 1994. La Scienza dell'Arte. Firenze: Giunti.

Kernodle, George R. 1944. From Art to Theatre. Chicago: University of Chicago Press.

Kruft, Hanno-Walter. 1988. Storia delle Teorie Architettoniche da Vitruvio al Settecento. Roma-Bari: Laterza.

Lenzi, Deanna. 2005. Sui Rapporti tra Quadraturismo e Scenografia: i Bibiena e la 'riforma del punto di vista'. In: Realtà e Illusione nell'Architettura Dipinta: Quadraturismo e Grande Decorazione nella Pittura di età Barocca, eds. Fauzia Farneti and Deanna Lenzi. Firenze: Alinea.

Lenzi, Deanna. 1991. Ferdinando e Francesco Bibiena. I "grandi padri" della Veduta per Angolo. In: Architetture dell'Inganno. Cortili Bibieneschi e Fondali Dipinti nei Palazzi Storici Bolognesi ed Emiliani, eds. Anna Maria Matteucci and Anna Stanziani. Bologna: Ars Arcadiae.

Mancini, Franco. 1979. Il 'trucco' Urbano: Apparati e Scenografie tra Finzione e Realtà. In: Civiltà del '700 a Napoli 1734-1799. Firenza: Centro Di.

Matteucci, Anna Maria 1982. L'Influenza della "veduta per angolo” sull'Architettura Barocca Emiliana. In: La Scenografia Barocca. Atti del XXIV Congresso Internazionale di Storia dell'Arte. Bologna: CLUEB.

Negri Arnoldi, Francesco. 1983. Scenografi, Prospettici e Vedutisti. In: Enciclopedia Universale dell'Arte, s.v. 'Prospettici e Quadraturisti', XI, 99-116. Novara: Istituto Geografico De Agostini.

Povoledo, Elena. 1983. La Prospettiva ad Angolo e la Scena-Quadro Rococò. In: Enciclopedia Universale dell'Arte, s.v. 'Scenografia', XII, 245-287. Novara: Istituto Geografico De Agostini.

Perrelli, Franco. 2004. Storia della Scenografia. Roma: Carocci.

Rabreau, Daniel. 2001. Les Dessins d'Architecture au XVIII Siècle. Paris: Bibliothèque de l'Image.

Ruffini, Franco. 1972. Per una Epistemologia del Teatro del '700: lo Spazio Scenico di Ferdinando Galli Bibiena. Biblioteca Teatrale 3: 1-7.

Stefano Chiarenza is research fellow at the San Raffaele Open University of Rome and is enabled to the functions of Associate Professor in the academic discipline of Representation of Architecture. In 2003, he obtained the Ph.D. in Survey and Drawing Representation of Architecture and Environment at the University of Naples "Federico II". Since the year 2002 he served on the courses of studies in Architecture, Engineering and Graphic Design at the University of Naples "Federico II" as well as at the Academy of fine Arts in Naples, with research and teaching responsibilities in Representation and Drawing. An underlying theme of his research program is the role of geometry and drawing as knowledge instruments. His research also focuses on architectural, archeological and environmental survey. On these research themes he has published or presented over 40 papers (including monographs, articles on review, articles in volumes or papers in conference proceedings). 